\title{
Competition and efficiency among Vietnam's commercial banks
}

\author{
PHAN THI THOM \\ University of Economics HCMC - thomphan2002@gmail.com \\ THAN THI THU THUY \\ University of Economics HCMC - thuynh@ueh.edu.vn
}

\section{ARTICLE INFO ABSTRACT}

Article history:

Received:

Dec. 10, 2015

Received in revised form:

May 26, 2016

Accepted:

Dec. 31,2016

Keywords:

Competition

Efficiency

Commercial banks.
This article investigates the impact of bank competition on cost and profit efficiency in the Vietnam's commercial banking system during 2005-2014. Based on different testing techniques, our results agree with the findings of Turk-Ariss (2010) that bank competition has a negative effect on profit efficiency and those of Pruteanu-Podpiera et al. (2008) and Maudos and de Guevara (2007) that bank competition is negatively related to cost efficiency. We also find that inflation and lag of competition are the two factors affecting the competition among these banks. 


\section{Introduction}

The competition-efficiency relation has been known for long through the neoclassical school, which maintains that perfect competition (monopoly) is the most (least) efficient. Oligopoly and monopolistic competition, moreover, are between the two extremes (Boyes \& Melvin, 1991; Byrns \& Stone, 1995; McEachern, 1994). The initiation of quiet life and efficient-structure hypotheses has made this relation become of more interest to many economists.

Adopting Granger causality, a number of empirical investigations attain dissimilar results: (i) competition improves efficiency (Andries \& Căpraru, 2014; Schaeck \& Cihák, 2008); (ii) competition does certain harm to efficiency (Maudos \& de Guevara, 2007; Pruteanu-Podpiera et al., 2008), and (iii) competition does no harm to efficiency (Fungácová et al., 2013). Furthermore, Turk-Ariss (2010) documented that increased competition would reduce profit efficiency yet enhance cost efficiency.

In fact, Turk-Ariss (2010), using a dataset of banks in 60 developing countries (including Vietnam) for the 1999-2005 period, attained the overall results of competition effects on efficiency. Are these results, however, applicable to the case of Vietnam's banking system over such a turbulent period as 2005-2014?

The primary aim of this study is to consider the nexus between bank competition and efficiency. Its novel idea, compared to others', is the inclusion of the factor of competition in the inefficiency function, without concerning Granger causality. to investigate the competition effects in Battese and Coelli's (1995) model. Second, the paper uses an efficiency model proposed by Tabak and Tecless (2010), which does not follow the approach of Turk-Ariss (2010), and then employs Turk-Ariss (2010)'s two-step approach to test for the impact of competition on efficiency in new conditions instead of checking robustness of difference or system GMM estimation and by re-estimating the model using three lags as Fungacova et al. (2013) or using OLS, fixed effects, or random effects techniques as Casu and Girardone (2009). The results demonstrate the negative effects of competition on profit efficiency, consistent with Turk-Ariss (2010), but it is shown that competition also negatively affects cost efficiency in 2005-2014, which, despite being opposite to TurkAriss's (2010) findings, supports the ones achieved by Podpiera Pruteanu et al. (2008) and Maudos and de Guevara (2007).

The negative influence of competition on efficiency is taken as a basis for examining the determinants of competition. Are low economic growth, high inflation, a large number of banks, or bank competition conducive to competition's harm to bank efficiency among Vietnam's banking institutions during the period under consideration. To date, only a few studies take note of competition determinants. Bikker and Haaf (2002) found certain negative effects on competition, whereas there was no evidence of the negative correlation between bank competition and concentration as detected by Claessens and Laeven (2004), in addition 
to Pruteanu-Podpiera et al. (2008), who concluded no significant impact of concentration on competition. Those three studies have not considered the lag of competition in current conditions. By adopting system GMM estimator, as well as OLS and fixed effects methods, we explore two determinants of competition in the Vietnam's banking system between 2005 and 2014. These factors consist of inflation and lag of competition.

\section{Theoretical bases}

2.1. Literature on the relationship between competition and efficiency

Theories of neoclassical economics maintain that in order to maximize profits, perfect competitors produce at a point where price equals marginal cost (MC), equals marginal revenue (MR), and also equals average total cost (ATC) (Figure 1). Perfect competition achieves both productive and allocative efficiency, while monopolistic competition does not (Boyes \& Melvin, 1991; Byrns \& Stone, 1995; McEachern, 1994). Monopolistic competition achieves productive inefficiency, i.e. there is no production at the minimum average cost (Byrns \& Stone, 1995). Monopoly creates deadweight loss, and hence is less efficient than competitive environment. As a whole, the neoclassical theory implies that perfect competition (monopoly) is the most (least) efficient, whereas oligopoly and monopolistic competition lie somewhere between.

Unlike the static approach adopted by neo-classical economists, dynamic Austrian and Schumpeter's approaches to the analysis of competition have gone far beyond the scope of neoclassical economics since competition is linked with innovation, imperfect knowledge, and the role of entrepreneurs. Competition, according to Schumpeter's theory, consists of five distinct types of innovation: (i) introduction of new products; (ii) introduction of new methods of production; (3) opening of new markets; (4) exploitation of new supply sources; and (5) implementation of new ways of business organization in any industry, such as ability to establish a monopolistic position (Nelson \& Winter, 2009). Monopolistic position, in this sense, differs fundamentally from the concept of monopoly as per neoclassical theories in that it is such a temporary phenomenon that allows banks to obtain substantial profits on account of improvements (Lipczynski et al., 2005).

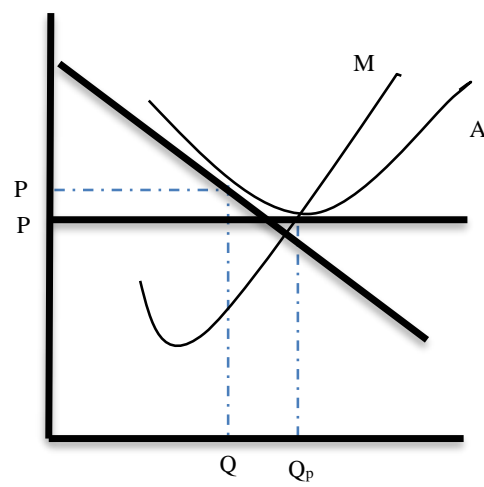

Figure 1. Perfect competition vs. monopolistic competition

Source: Boyes and Melvin (1991), Frank and Bernanke (2004), Miller (2005)

\subsection{Hypotheses on the competition-effi-} ciency relation

Considered to verify the nexus between competition and efficiency are the following 
hypotheses:

\section{Quiet life hypothesis}

The quiet life hypothesis postulates that the higher the market power, the less great the effort of management to maximize operational efficiency. Therefore, there exists a negative correlation between market power and efficiency (Maudos \& de Guevara, 2007). This implies that increased market power reduces the operational efficiency of the bank, or in other words, more fierce competition enhances bank efficiency.

\section{Efficiency structure hypothesis}

Proposed by Demsetz (1973), it postulates that higher profits and market share can be attained by the most efficient banks, and as a result, the market becomes more concentrated. Since concentration is deemed a revere measure of competition, higher efficiency is synonymous with less severe competition.

\section{Bank-specific hypothesis}

Pruteanu-Podpiera et al. (2008), in developing this hypothesis, argued that the banking sector is perceived to obtain some specific characteristics distinct from others due to asymmetric information in such an imperfect competitive market. Therefore, banks need to solve the problems of adverse selection and moral hazard.

To solve the puzzle they maintain longrun relations with borrowers. Increased competition, nevertheless, can push up the cost of monitoring owing to existing economies of scale and impair customer relations in long terms. This means that there exists a negative competition-efficiency correlation.

\subsection{Review of previous literature}

Up to now there has been plenty of empirical research on the relationship between competition and efficiency at both multinational level (Andries \& Capraru, 2014; Casu $\&$ Girardone, 2009; Maudos \& de Guevara, 2007; Schaeck \& Cihak, 2008; Turk-Ariss, 2010) and national level (Fungacova et al., 2013; Pruteanu-Podpiera et al., 2008). Notably, profit and cost efficiency are emphasized in the majority of multinational studies, yet at the national scope little has been mentioned concerning the issue of profit efficiency.

Two among the aforementioned studies, considering cost efficiency, rejected the quiet life hypothesis (Maudos \& de Guevara, 2007; Pruteanu-Podpiera et al, 2008. Also inspecting this relationship, Schaeck and Cihak (2008) found a positive impact of competition on profit efficiency, using a sample of European and American banks in 1995-2005. More recently, Andries and Capraru (2014) detected a positive competition-efficiency correlation for the case of European banking institutions from 2004 through 2010. In addition, the entirely different results of this relation were achieved by Fungacova et al. (2013), who studied Chinese banks over the period of 20022011, arguing that increased competition does no harm to cost efficiency.

To investigate the nexus between competition and efficiency most studies have used Granger causality in addition to system and difference GMM estimators, or fixed effects method. Diverging from those studies, TurkAriss (2010) adopted Battese and Coelli's 
(1992) estimation of efficiency function and used Tobit model to examine the impact of competition (Lerner index) on efficiency of 60 developing countries during 1999-2005. This author found that increased market power enhances profit efficiency, which is in contrast to the quiet life hypothesis and also the findings of Schaeck and Cihak (2008). In terms of cost efficiency, the results of TurkAriss (2010), however, advocated the quiet life hypothesis.

Accordingly, the system and difference GMM estimators have been universally used among the earlier investigations. We are aware that no study employed the approach of Battese and Coelli (1995), comparing the results using two steps as approached by Turk-Ariss (2010).

Unlike the case of research into the competition-efficiency linkage, there have been not much to take into account determinants of competition. Bikker and Haaf (2002), using competition-measuring index (H statistic) for a dataset of 23 industrialized countries within 10 years, documented that concentration negatively affects competition. The work also illustrated that the larger the number of banks, the less severe the competition, against the early expectations of the authors. Employing a larger sample size of 50 countries and also the $\mathrm{H}$ index for the 1994-2001 period, Claessens and Laeven (2004) showed that more bank concentration is attributable to more competition. This result disagrees with the structure-conductperformance hypothesis, which maintains that a negative association exists between concentration and competition. On the other hand, the findings of Pruteanu-Podpiera et al. (2008) found no significant impact of the concentration on competition in the Czech banking sector during 1994-2005. Instead, the GDP growth was indicated to exert a significantly positive impact on competition in the country. One point in common from these three studies is that they take no account of endogeneity caused by lags of the dependent variable (competition). Fungácová et al. (2013) argued that competition in the present term is affected by that in the previous one, but looked merely at the effect of efficiency on competition.

In this study, apart from examining the competition effect on bank efficiency, we consider determinants of bank competition. This is expected to be of great usefulness, exclusively in the event that competition impacts negatively on efficiency in the $\mathrm{Vi}$ etnam's banking system. Also inspected is the endogeneity and others by using system GMM technique for surveying the factors affecting bank competition between 2005 and 2014.

\section{Methodology}

\subsection{Data}

Data in this study was obtained from Bankscope. After elimination of missing observations and negative values of inputs and outputs, the sample includes 31 banks (one state-owned bank, Agribank; four commercial banks with large state shareholding, Vietinbank, BIDV, Vietcombank, and MHB; 26 joint-stock commercial banks) and 250 observations for the period of 2005-2014. 


\subsection{Models}

\section{Measuring competition}

Many indices have been proposed for competition measures, such as $\mathrm{H}$ index (Panzar \& Rosse, 1987), Boone index (Boone, 2008), and Lerner index, used to estimate market power. All of these indices have been developed by New Empirical Industrial Organization (NEIO). In particular, the Lerner index is preferred to the traditional ones measuring the market structure (Beck et al., 2013; Turk-Ariss, 2010). Furthermore, Phan and Than (2015) argued that the Lerner index is more suitable for measuring competition in the banking system in comparison with the others. Therefore, within the scope of this study, we employ the Lerner index.

Although marginal cost cannot be observed in a direct manner, many different approaches have been adopted to measure it. We employ Fu et al.'s (2014) ${ }^{1}$ technique with three input factors in two steps as follows:

Step 1: Estimating cost function parameters:

$$
\begin{gathered}
\ln \frac{T C_{i t}}{w_{3, i t}}=\alpha_{0}+\alpha_{1} \ln T A_{i t}+ \\
\frac{1}{2} \delta_{1} \ln T A_{i t}^{2}+\sum_{k=1}^{2} \beta_{j} \ln \frac{w_{k, i t}}{w_{3, i t}}+ \\
\frac{1}{2} \sum_{j=1}^{2} \sum_{k=1}^{2} \gamma_{j k} \ln \frac{w_{j, i t}}{w_{3, i t}} \ln \frac{w_{k, i t}}{w_{3, i t}}+ \\
\sum_{k=1}^{2} \rho_{k} \ln T A_{i t} \ln \frac{w_{k, i t}}{w_{3, i t}}+\theta_{1} T+\frac{1}{2} \theta_{2} T^{2}+ \\
\tau_{1} T \ln T A_{i t}+\sum_{k=1}^{2} \omega_{k} T \ln \frac{w_{k, i t}}{w_{3, i t}}+\varepsilon_{i t}
\end{gathered}
$$

where $T C_{i t}$ is total cost (including interest expense, employee expense, and other noninterest expenses); $T A_{i t}$ is total assets; $w_{l, i t}$ is labor cost; $w_{2, i t}$ is interest expense; $w_{3, i t}$ is raw material cost measured by ratio of employee expense to total assets ${ }^{2}$, ratio of interest expense to total deposit, and ratio of other noninterest expenses to fixed assets ${ }^{3}$; and $T$ denotes time trend to capture the impact of technological changes which lead to changes in the production function over time ${ }^{4}$.

Equation (1) is estimated for each bank ( $\mathrm{i}$ $=1, \ldots, 31)$ for 10 years $(t=1, \ldots, 10)$. Total cost and input cost are divided by $w_{3}$ to ensure linear homogeneity. Apart from the variable $T$, logarithm is taken for the others.

Step 2: We take first derivative of the dependent variable in Equation (1) for each bank's marginal cost as follows:

$$
M C_{i t}=\frac{\partial T C_{i t}}{\partial T A_{i t}}=\frac{T C_{i t}}{T A_{i t}}\left(\alpha_{1}+\delta_{1} \ln T A_{i t}+\right.
$$

$\left.\sum_{k=1}^{2} \rho_{k} \ln \frac{w_{k i t}}{w_{3 i t}}+\tau_{1} T\right)$

Then. the Lerner index is computed as:

$$
\text { Lerner }_{i t}=\frac{P_{i t}-M C_{i t}}{P_{i t}}
$$

where $P$ denotes average output price of bank $i, P_{i t}$ is total income ratio (sum of interest income and non-interest income/total assets), and $M C_{i t}$ is marginal cost of bank $i$ at period $t$.

Lerner $=0$ implies perfect competition, whereas Lerner $=1$ implies the existence of monopoly. The more the Lerner index is equal to 1 , the greater the market power and the less severe the competition in the market.

\section{Measuring competition and efficiency}

Bank efficiency can be measured using different techniques. Two of them, however, have been most universally adopted, including data envelopment analysis (DEA) and stochastic frontier analysis (SFA). Although 
DEA has been a preference, the method does not provide as good insights into market structure and firms' behavior as the other (Feng \& Serletis, 2010).

SFA allows for a series of applied methods depending on varied hypotheses. According to Battese and Coelli (1995), measuring the efficiency function does enable the estimation of both efficiency and inefficiency parameters within one step. This approach is expected to be more effective than the two-step one ${ }^{5}$, and thus we base on Battese and Coelli (1995) to compute the cost function proposed by Tabak and Teckless (2010) as below:

$$
\begin{aligned}
& \ln \frac{T C_{i t}}{w_{3, i t}}=\alpha_{0}+\sum_{a=1}^{4} \beta_{a} \ln Q_{a, i t}+ \\
& \frac{1}{2} \sum_{a=1}^{4} \sum_{b=1}^{4} \beta_{a b} \ln Q_{a, i t} \ln Q_{b, i t}+ \\
& \sum_{k=1}^{2} \gamma_{k} \ln \frac{w_{k, i t}}{w_{3, i t}}+ \\
& \frac{1}{2} \sum_{j=1}^{2} \sum_{k=1}^{2} \delta_{j k} \ln \frac{w_{j, i t}}{w_{3, i t}} \ln \frac{w_{k i t}}{w_{3 i t}}+ \\
& \sum_{a=1}^{4} \sum_{k=1}^{2} \rho_{a k} \ln Q_{a, i t} \ln \frac{w_{k, i t}}{w_{3, i t}}+\theta_{1} T+ \\
& \frac{1}{2} \theta_{2} T^{2}+\sum_{k=1}^{2} \varphi_{k} T \ln \frac{w_{k, i t}}{w_{3, i t}}+ \\
& \sum_{a=1}^{4} \omega_{a} T \ln Q_{a, i t}+\vartheta_{i t}+\mu_{i t}
\end{aligned}
$$

where $T C_{i t}$ is total cost (including interest expense, employee expense, and other non-interest expenses); $Q_{a, i t}$ is output, including net loans, other earning assets, total deposits, and off-balance sheet assets; $w_{k, i t}$ is input cost, including $w_{1, i t}$ (labor cost), $w_{2, i t}$ (interest expense), and $w_{3, i t}$ (raw material cost), calculated as in Equation (1).

Total cost and input cost are divided by $w_{3, i t}$ to ensure linear homogeneity. $T$ is time trend, taking into account technological changes attributed to changes in the produc- tion function over time; $\mu$ is technical inefficiency; and $i$ and $t$ are as defined in Equation (1).

Similar to Tabak and Tecless (2010) and Andries and Căpraru (2014), in this study we propose inefficiency estimator $\mu$. As per previous findings, competition affects efficiency (Andries \& Căpraru, 2014; Casu \& Girardone, 2009; Pruteanu-Podpiera et al., 2008; Schaeck \& Cihák, 2008). Besides Granger causality, we introduce to the inefficiency model the variable competition to capture the effects of competition on cost efficiency and profit efficiency and then employ Battese and Coelli (1995) for our estimation. Incorporating the independent variables of Tabak and Tecless (2010) and Andries and Căpraru (2014), the inefficiency equation is as follows:

$$
\begin{gathered}
\mu_{i t}=\omega_{0}+\omega_{1} E A_{i t}+\omega_{2} \text { Lerner }_{i t}+ \\
\omega_{3} \text { lnT } A_{i t}+\omega_{4} \text { State }+\omega_{5} \text { Public }^{+} \\
\omega_{6} \text { Foreign }++\omega_{7} I N F_{t}+\omega_{8} \text { GDPG } G_{t}+\varepsilon_{i t}
\end{gathered}
$$

where $E A_{i t}$ is ratio of equity on total assets, $\ln T A$ is total assets in logarithm, State is a dummy variable ( $=1$ if being state-owned commercial bank, and 0 otherwise), Public is a dummy variable of the listed bank ( $=1$ if listed, and 0 otherwise), Foreign is a dummy variable of foreign ownership ( $=1$ if foreign shares are held, and 0 otherwise), INF is inflation, and GDPGr is GDP growth rate.

Bank efficiency in accordance with the cost efficiency model ${ }^{6}$ is represented by:

$$
E F F C_{i t}=\exp \left(u_{i t}\right)
$$

Equation for estimating profit is constructed as: 


$$
\begin{gathered}
\ln \frac{\pi_{i t}}{w_{3}}=\alpha_{0}+\sum_{a=1}^{4} \beta_{a} \ln Q_{a i t}+ \\
\frac{1}{2} \sum_{a=1}^{4} \sum_{b=1}^{4} \beta_{a b} \ln Q_{a i t} \ln Q_{b i t}+ \\
\sum_{k=1}^{2} \gamma_{k} \ln \frac{w_{k i t}}{w_{3 i t}}+ \\
\frac{1}{2} \sum_{j=1}^{2} \sum_{k=1}^{2} \delta_{j k} \ln \frac{w_{j i t}}{w_{3 i t}} \ln \frac{w_{k i t}}{w_{3 i t}}+ \\
\sum_{a=1}^{4} \sum_{k=1}^{2} \rho_{a k} \ln Q_{a i t} \ln \frac{w_{k i t}}{w_{3 i t}}+\theta_{1} T+ \\
\frac{1}{2} \theta_{2} T^{2}+\sum_{k=1}^{2} \varphi_{k} T \ln \frac{w_{k i t}}{w_{3 i t}}+ \\
\sum_{a=1}^{4} \omega_{a} T \ln Q_{a i t}+\vartheta_{i t}-\mu_{i t}
\end{gathered}
$$

where $\pi_{i t}$ represents after-tax profit, and the other variables are as defined in Equation (4).

Bank efficiency in accordance with the profit efficiency model $^{7}$ is computed as:

$$
\operatorname{EFFPra}_{i t}=\exp \left(-u_{i t}\right)
$$

Model of competition-efficiency proposed by Turk-Ariss (2010)

In light of Turk-Ariss (2010), we estimate Equations (4) and (7) using Battese and Coelli's (1992) approach and then performing Tobit regression analysis ${ }^{8}$ of independ-

\begin{tabular}{|c|c|c|c|}
\hline Variable & Definition & Sources & References \\
\hline Lerner & measure of competition & Authors' calcu- & Turk-Ariss, 2010 \\
\hline Lerner_sq & $\begin{array}{l}\text { measure of square of com- } \\
\text { petition }\end{array}$ & lations & Turk-Ariss, 2010 \\
\hline LA & loans/total assets & Bankscope & Turk-Ariss, 2010 \\
\hline $\operatorname{lnTA}$ & $\log$ of total assets & Bankscope & Turk-Ariss, 2010 \\
\hline $\operatorname{lnGDPPC}$ & log of GDP per capita & Worldbank & Turk-Ariss, 2010 \\
\hline Legal & measure of legal terms & Worldbank & Turk-Ariss, 2010 \\
\hline GDPGr & GDP growth rate & Worldbank & $\begin{array}{l}\text { Pruteanu-Podpiera et al. } \\
\text { (2008) }\end{array}$ \\
\hline INF & measure of inflation & Worldbank & $\begin{array}{l}\text { Pruteanu-Podpiera et al. } \\
\text { (2008), Claessens and } \\
\text { Laeven (2004) }\end{array}$ \\
\hline lnbanks & $\begin{array}{l}\text { log of total number of com- } \\
\text { mercial banks }\end{array}$ & $\begin{array}{l}\text { Bankscope and } \\
\text { vietstoc.vn }\end{array}$ & Bikker and Haaf (2002) \\
\hline HHI_asset & $\begin{array}{l}\text { bank asset concentration, } \\
\text { measured by sum of } \\
\text { squared market shares of } \\
\text { the bank }\end{array}$ & $\begin{array}{l}\text { Authors' calcu- } \\
\text { lations }\end{array}$ & Bikker and Haaf (2002) \\
\hline
\end{tabular}
ent variables as follows:

$$
\begin{array}{r}
E F F_{i t}=\alpha_{0}+\beta_{1} \text { Lerner }_{i t}+\beta_{2} \text { Lerner_sq }_{i t}+ \\
\beta_{3} L A_{i t}+\beta_{3} \text { lnTA }_{i t}+\beta_{4} \ln \text { GDPPC } C_{t}+\beta_{5} \text { Legal }_{t}
\end{array}
$$$$
+\varepsilon_{i t}
$$

where EFF, an efficiency index, includes

\section{Table 1}

Description of variables 
EFFC (cost efficiency) and EFFPra (profit efficiency $)^{9}$ and the other variables are reported in Table 1.

The equation is calculated using bootstrapped standard error.

\section{Identifying determinants of competition}

Next, we construct the equation of determinants of bank competition as below:

Lerner $_{i t}=\alpha_{0}+\beta_{1}$ Lerner $_{i, t-1}+\delta_{1} H H I \_$asset $_{t}$ $+\delta_{2} G D P G r_{t}+\delta_{3} I N F_{t}+\delta_{4}$ lnbanks $_{t}+\varepsilon_{i t}(10)$ where all variables in Equation (10) are as defined in Table 1.

According to Roodman (2009), difference and system GMM approaches have been based upon data generating procedures. Those are dynamic in conjunction with existence of the dependent variable being affected by itself in the past, endogeneous variables, and idiosyncratic disturbances or the likelihood of heteroskedasticity, serial correlation, uncorrelated disturbances, and small T, large $\mathrm{N}$.

The difference GMM approach developed by Arellano and Bond (1991) uses lag of variables as instruments for first difference equation. It allows for first-order autocorrelation but not others. Hansen's $\mathrm{J}$ is also employed to test the values of instruments. Besides that, in this study we adopt the system GMM technique since its simultaneous estimation at both level and differences offers more effectiveness in estimating coefficients (Arellano \& Bover, 1995; Blundell \& Bond, 1998).

Bond (2002) argued that GMM is most appropriate for dynamic panels. In addition to handling the problem of endogeneity caused by the dependent variable, difference

\section{Table 2}

Estimation results of inefficiency (including competition)

\begin{tabular}{lcccc}
\hline & \multicolumn{2}{c}{ Inefficiency $($ cost $)$} & \multicolumn{2}{c}{ Inefficiency (profit) } \\
\hline $\begin{array}{l}\text { Independent var- } \\
\text { iable }\end{array}$ & Coef. & t-value & Coef. & t-value \\
\hline EA & $-0.103^{* * *}$ & -4.37 & -0.00259 & -0.12 \\
State & $-5.646^{* * *}$ & -5.42 & $1.167 * *$ & 2.23 \\
Public & 22.79 & 1.09 & $13.96^{*}$ & 1.71 \\
Foreign & $4.747^{* * *}$ & 6.08 & $3.500^{* * * *}$ & 5.74 \\
lnTA & -0.024 & -0.33 & -10 & \\
INF & -11 & & $0.244^{* * * *}$ & 4.74 \\
Lerner & $-38.32^{* * *}$ & -9.29 & $-23.64 * * *$ & -14.16 \\
Obs. & 252 & & & 252 \\
\hline
\end{tabular}

$* \mathrm{p}<0.1 ; * * \mathrm{p}<0.05 ; * * * \mathrm{p}<0.01$ 
and two-step system GMM approaches allow for first-order autocorrelation with errors. As discussed, we utilize both of them and also take into account OLS and fixed effects method to check robustness of the results.

\section{Results}

\subsection{Impact of competition on efficiency}

Results of competition measure using Battese and Coelli (1995)

The estimated results achieved by employing Battese and Coelli's (1995) method for both cost and efficiency functions in Table 2 show that the Lerner index has a negative effect on inefficiency at $1 \%$ level and that its impact is far more powerful than effects of the others. This implies that the higher the Lerner index (decreased competition), the lower the cost and profit inefficiency (the higher the cost and profit efficiency). Thus, more severe competition will reduce efficiency (both cost and profit efficiency).

Results of competition measure using Turk-Ariss (2010)

The results in Table 3 report the positive effect of the Lerner index on cost efficiency at $10 \%$ level, which means that competition negatively affects cost efficiency. The findings underpin the arguments of Battese and Coelli (1995), Pruteanu-Podpiera et al. (2008), and Maudos and de Guevara (2007).

\section{Table 3}

Estimation results using two-step approach

\begin{tabular}{|c|c|c|c|c|}
\hline \multirow{2}{*}{$\begin{array}{c}\text { Dependent variable } \\
\text { Independent variable }\end{array}$} & \multicolumn{2}{|c|}{ Cost efficiency (EFFC) } & \multicolumn{2}{|c|}{ Profit efficiency (EFFPra) } \\
\hline & Coef. & t-value & Coef. & t-value \\
\hline Lerner & $0.0007 *$ & 1.89 & $1.288 * * *$ & 3.75 \\
\hline Lerner_sq & $-0.0019 *$ & -1.85 & -0.866 & -1.03 \\
\hline LA & $-0.0002 * * *$ & -2.71 & $0.200 * * *$ & 2.75 \\
\hline $\operatorname{lnTA}$ & 0.00001 & 1.36 & $-0.0362 * * *$ & -2.73 \\
\hline $\operatorname{lnGDPPC}$ & $-0.0004 * * *$ & -11.64 & $0.131 * *$ & 2.33 \\
\hline Legal & $0.0001 * * *$ & 10.11 & 0.012 & 0.51 \\
\hline _cons & $1.007 * * *$ & 1671.19 & $-1.488 *$ & -1.75 \\
\hline Inflection point & \multicolumn{2}{|c|}{0.1872} & \multicolumn{2}{|c|}{-} \\
\hline Correlation sign & \multicolumn{2}{|c|}{+} & \multicolumn{2}{|c|}{+} \\
\hline Obs. & \multicolumn{2}{|c|}{250} & \multicolumn{2}{|c|}{250} \\
\hline
\end{tabular}

$* \mathrm{p}<0.1 ; * * \mathrm{p}<0.05 ; * * * \mathrm{p}<0.01$ 
Hence, the quiet life hypothesis can be rejected.

In addition, the Lerner index impacts positively on profit efficiency at $1 \%$ level, which suggests that an increase (reduction) in the index (competition) is conducive to increased profit. This result is consistent with the estimated results of Battese and Coelli (1995) and also Turk-Ariss (2010).

\subsection{Determinants of competition}

By employing difference and system $\mathrm{GMM}^{12}$ as well as OLS and fixed effects methods, the results in Table 4 indicate that one-year lag of the Lerner index and inflation (INF) are two determinants of the Lerner index itself. The impacts are significant with the correlation sign being constant for all the four estimators.

\section{Table 4}

Estimation results of determinants of competition

\begin{tabular}{|c|c|c|c|c|}
\hline & Lerner & Lerner & Lerner & Lerner \\
\hline \multirow{3}{*}{ Lerner $_{\mathrm{t}-1}$} & dif-GMM & sys-GMM & OLS & $\mathrm{FE}$ \\
\hline & $0.215^{*}$ & $0.462 * * *$ & $0.688 * * *$ & $0.187 * * *$ \\
\hline & {$[1.68]$} & {$[4.30]$} & [14.20] & {$[2.81]$} \\
\hline \multirow[t]{2}{*}{ HHI_asset } & -0.00003 & -0.00007 & 0.00003 & $0.00004^{*}$ \\
\hline & {$[-0.74]$} & {$[-0.41]$} & {$[1.41]$} & {$[1.80]$} \\
\hline \multirow[t]{2}{*}{ GDPGr } & 0.0405 & 0.0831 & 0.0109 & $0.0359 * * *$ \\
\hline & {$[0.45]$} & {$[0.27]$} & {$[1.25]$} & [4.51] \\
\hline \multirow[t]{2}{*}{ INF } & $-0.0086^{* * *}$ & $-0.0106 * * *$ & $-0.0079 * * *$ & $-0.0059 * * *$ \\
\hline & {$[-3.93]$} & {$[-2.82]$} & {$[-8.86]$} & {$[-7.42]$} \\
\hline \multirow[t]{2}{*}{ lnbanks } & 0.887 & 1.427 & $0.499 * * *$ & $0.759 * * *$ \\
\hline & {$[0.42]$} & {$[0.28]$} & {$[3.75]$} & {$[6.52]$} \\
\hline $\mathrm{AR}(1)$ & 0.019 & 0.006 & & \\
\hline $\operatorname{AR}(2)$ & 0.975 & 0.861 & & \\
\hline Hansen $\mathrm{J}$ & 0.915 & 0.991 & & \\
\hline Obs. & 183 & 216 & 216 & 216 \\
\hline
\end{tabular}

$* \mathrm{p}<0.1 ; * * \mathrm{p}<0.05 ; * * * \mathrm{p}<0.01$ 
Thus, it implies that their effects on competition are rather robust.

The impact of lag of competition carries the positive sign, implying that severe competition in the previous term results in the similar case occurring in the current one. The negative effect of INF on the Lerner index suggests that higher inflation contributes to increased competition, which should be due to increased lending rate caused by a rise in inflation rates. Consequently, as there is a likelihood that firms and individual customers gain no access to finance from commercial banks, which badly affects their costs and profitability, banks' lending activities become stagnant, and this creates an urgent need for mutual competition to find one for financing.

Furthermore, in this study insufficient evidence has been collected to conclude that bank concentration, GDP growth, and the number of banking institutions have effects on competition among Vietnam's banking institutions between 2005 and 2014.

\section{Conclusion and policy implications}

\subsection{Conclusion}

Economic theories have contributed to vigorous debates over the competition-efficiency nexus for decades, and not until the introduction of such hypotheses as quite life or efficient structure did the relation become more universally known. A range of empirical findings attained from studies on the banking sector that vary in size and scope proved not to be completely consistent.

In this study by adopting Battese and Coelli's (1995) estimator as well as the two- step approach of Turk-Ariss (2010) for a sample of 31 commercial banking institutions in Vietnam over the period of 20052014, we find that competition exerts a negative impact on profit efficiency, supporting Turk-Ariss's (2010) findings. Competition is also suggested to negatively affect cost efficiency in the same period, consistent with Pruteanu-Podpiera et al. (2008) and Maudos and de Guevara (2007).

Additionally, through the application of difference GMM and system GMM besides OLS and fixed effects methods, two factors have been found to have effects on competition to include competition in the previous term and inflation. Particularly, the result suggesting that competition in the present term is affected by that in the previous one is in agreement with Fungácová et al.'s (2013) findings, whereas the inflation effect on competition was not documented in earlier investigations.

\subsection{Implications}

From the research results, it is necessary for Vietnam's commercial banks to be aware that increasing competition would lower bank efficiency, and that competition is affected positively by itself in the previous term and inflation. Cutting input costs should, therefore, be considered in order to increase efficiency for these banks. Furthermore, increasing the output is another option to improve bank efficiency by expanding their markets or enhancing the quality of banking services. In addition, the essential role of entrepreneurs, creators for competitiveness and economic performance, should be more emphasized according to Austrian 
and Shumpeter's schools of thought, which rings quite true especially for today's competitive environment.

To enhance bank efficiency under high pressure of increasing degrees of inflation and competition, it is also important to consider policies on curbing inflation in coming years. In addition, to reduce competition among banking institutions, the central bank should coordinate with other departments to formulate synchronous mechanisms, which, at the same time, promote the development of other industries. In parallel with this move, the central bank needs to encourage banks' investment in various domains currently not appreciated (e.g., lending to the agricultural sector)

\section{Notes}

${ }^{1}$ Fu et al. (2014) argued that due to insufficient data of labor, non-interest cost is used as a proxy for labor cost and raw material cost.

${ }^{2}$ The number of total employees has not been reported in most financial statements of Vietnam's commercial banks. This is also true for other countries. Thus, we adopt the measure of labor cost in accordance with Berger et al. (2009), and Andries and Căpraru (2014).

${ }^{3}$ Due to a lack in data of fixed assets, several studies have employed total assets as a substitute. ${ }^{4} \mathrm{~T}$ = year to be studied - the starting year of the study period

${ }^{5}$ According to the two-step approach, technical inefficiency is considered in the second step after forecasting and measuring inefficiency in the first one.

${ }^{6}$ Berger and Mester (1997) argued that cost efficiency allows one to estimate the degree of close- ness of a bank's cost against that of a best-practice bank when producing a similar output in similar circumstances. As such, technical inefficiency, according to this approach, uses too many inputs to create outputs.

${ }^{7}$ As documented by Berger and Mester (1997), there are two types of profit efficiency: standard and alternative. Standard profit efficiency estimates the gap between a bank's performance and the generation of the highest possible earning concerning a particular degree of input and output prices. Alternative profit efficiency is calculated by how likely a bank makes the highest profit with a given degree of output instead of the bank's output prices.

${ }^{8}$ As the efficiency index ranges between 0 and 1 , Tobit regression is believed to be suitable for this case.

${ }^{9}$ It is indicated that the results of EFFC and EFFP estimation in Equation (9) are different from those in Equations (6) and (8). Still, this study uses similar symbols to avoid repetitions.

${ }^{10}$ This variable, when used for the profit efficiency model, causes losses in values of other variables and is therefore eliminated from our estimation.

${ }^{11}$ As per cost efficiency model, value losses are also subject to the use of the variable $I N F$, which is consequently removed from the estimate.

${ }^{12} \mathrm{AR}(2)$ and p-value of Hansen $\mathrm{J}$ in both difference GMM and system GMM estimators are larger than 0.1 , indicating no second-order autocorrelation and no rejection of the null hypothesis that the instruments are exogenous, respectively.

\section{References}

Andries, A. M., \& Căpraru, B. (2014). The nexus between competition and efficiency: The European banking industries experience. International Business Review, 23, 566-579. 
Arellano, M., \& Bond, S. (1991). Some tests of specification for panel data: Monte Carlo evidence and an application to employment equations. The Review of Economic Studies, 58(2), 277-297.

Arellano, M., \& Bover, O. (1995). Another look at the instrumental variable estimation of error-components models. Journal of Econometrics, 68(1), 29-51.

Battese, G. E., \& Coelli, T. J. (1992). Frontier production functions, technical efficiency and panel data: With application to paddy farmers in India. Journal of Productivity Analysis, 3(1-2), 153-169.

Battese, G. E., \& Coelli, T. J. (1995). A model for technical inefficiency effects in a stochastic frontier production function for panel data. Empirical Economics, 20, 325-332.

Beck, T., De Jonghe, O., \& Schepens, G. (2013). Bank competition and stability: Cross-country heterogeneity. Journal of Financial Intermediation, 22(2), 218-244.

Berger, A. N., Klapper, L. F., \& Turk-Ariss, R. (2009). Bank competition and financial stability. Journal of Financial Services Research, 35(2), 99-118.

Berger, A. N., \& Mester, L. J. (1997). Inside the black box: What explains differences in the efficiencies of financial institutions. Journal of Banking \& Finance, 21, 895-947.

Bikker, J. A., \& Haaf, K. (2002). Competition, concentration and their relationship: An empirical analysis of the banking industry. Journal of Banking \& Finance, 26(11), 21912214.

Blundell, R., \& Bond, S. (1998). Initial conditions and moment restrictions in dynamic panel data models. Journal of Econometrics, 87(1), 115-143.

Bond, S. R. (2002). Dynamic panel data models: A guide to micro data methods and practice.
Portuguese Economic Journal, 1(2), 141162.

Boone, J. (2008). A new way to measure competition. The Economic Journal, 118, 12451261.

Boyes, W., \& Melvin, M. (1991). Economics. MA: Houghton Mifflin Company.

Byrns, R. T., \& Stone, G. W. (1995). Economics $\left(6^{\text {th }}\right.$ Edition). NY: HarperCollins College.

Casu, B., \& Girardone, C. (2009). Testing the relationship between competition and efficiency in banking: A panel data analysis. Economics Letters, 105(1), 134-137.

Claessens, S., \& Laeven, L. (2004). What drives bank competition? Some international evidence. Journal of Money, Credit and Banking, 36(3), 563-583.

Demsetz, H. (1973). Industry structure, market rivalry, and public policy. Journal of Law and Economics, 16(1), 1-9.

Feng, G., \& Serletis, A. (2010). Efficiency, technical change, and returns to scale in large US banks: Panel data evidence from an output distance function satisfying theoretical regularity. Journal of Banking \& Finance, 34, 127-138.

Frank, R. H., \& Bernanke, B. S. (2004). Principles of Economics (2 ${ }^{\text {nd }}$ Edition). NY: McGraw-Hill/Irwin.

Fu, X., Lin, Y., \& Molyneux, P. (2014). Bank competition and financial stability in Asia Pacific. Journal of Banking and Finance, 38, 64-77.

Fungácová, Z., Pessarosi, P., \& Weill, L. (2013). Is bank competition detrimental to efficiency? Evidence from China. China Economic Review, 27, 121-134.

Lipczynski, J., Wilson, J., \& Goddard, J. (2005). Industrial organisation: Competition, strategy, policy ( $2^{\text {nd }}$ Edition). UK: Prentice Hall. 
Maudos, J., \& De Guevara, J. F. (2007). The cost of market power in banking: Social welfare loss vs. cost inefficiency. Journal of Banking and Finance, 31(7), 2103-2125.

McEachern, W. A. (1994). Economics: A contemporary introduction ( $3^{\text {rd }}$ Edition). TN: South-Western.

Miller, R. L. (2005). Understanding modern economics. Pearson Addison Wesley.

Nelson, R. R., \& Winter, S. G. (2009). An evolutionary theory of economic change. MA: Harvard University Press.

Panzar, J. C., \& Rosse, J. N. (1987). Testing for "monopoly" equilibrium. The Journal of Industrial Economics, 35(4), 443-456.

Phan, T. T., \& Than, T. T. T. (2015). Competition in Vietnam's commercial banking system (in Vietnamese). Journal of Economic Development, 26(7), 28-46.

Pruteanu-Podpiera, A., Weill, L., \& Schobert, F. (2008). Banking competition and efficiency:
A micro-data analysis on the Czech banking industry. Comparative Economic Studies, 50, 253-273.

Roodman, D. (2009). How to do xtabond2: An introduction to difference and system GMM in Stata. The Stata Journal, 9(1), 86-136.

Schaeck, K., \& Cihák, M. (2008). How does competition affect efficiency and soundness in banking? New empirical evidence. Working Paper Series No. 932. European Central Bank.

Tabak, B. M., \& Tecless, P. L. (2010). Estimating a Bayesian stochastic frontier for the Indian banking system. International Journal of Production Economics, 125, 96-110.

Turk-Ariss, R. (2010). On the implications of market power in banking: Evidence from developing countries. Journal of Banking and Finance, 34(4), 765-775. 